University of Nebraska - Lincoln

DigitalCommons@University of Nebraska - Lincoln

Faculty Publications from the Harold W. Manter Laboratory of Parasitology

2000

\title{
A New Eimeria sp. from the Plumbeous Central American Caecilian, Dermophis mexicanus (Amphibia: Gymnophiona) from Volcán, Tajumulco, Department of San Marcos, Guatemala
}

Ingrid M. Asmundsson

University of New Mexico

Jonathan A. Campbell

University of Texas at Arlington

Donald W. Duszynski

University of New Mexico, eimeria@unm.edu

Follow this and additional works at: https://digitalcommons.unl.edu/parasitologyfacpubs

Part of the Parasitology Commons

Asmundsson, Ingrid M.; Campbell, Jonathan A.; and Duszynski, Donald W., "A New Eimeria sp. from the Plumbeous Central American Caecilian, Dermophis mexicanus (Amphibia: Gymnophiona) from Volcán, Tajumulco, Department of San Marcos, Guatemala" (2000). Faculty Publications from the Harold W. Manter Laboratory of Parasitology. 135.

https://digitalcommons.unl.edu/parasitologyfacpubs/135

This Article is brought to you for free and open access by the Parasitology, Harold W. Manter Laboratory of at DigitalCommons@University of Nebraska - Lincoln. It has been accepted for inclusion in Faculty Publications from the Harold W. Manter Laboratory of Parasitology by an authorized administrator of DigitalCommons@University of Nebraska - Lincoln. 


\title{
A NEW EIMERIA SP. FROM THE PLUMBEOUS CENTRAL AMERICAN CAECILIAN, DERMOPHIS MEXICANUS (AMPHIBIA: GYMNOPHIONA) FROM VOLCÁN TAJUMULCO, DEPARTMENT OF SAN MARCOS, GUATEMALA
}

\author{
Ingrid M. Asmundsson, Jonathan A. Campbell*, and Donald W. Duszynski \\ Department of Biology, The University of New Mexico, Albuquerque, New Mexico 87131
}

\begin{abstract}
Fresh fecal samples from 5 caecilians (Dermophis mexicanus) were collected and examined for coccidia in the summer of 1998. The caecilians were collected in the Department of San Marcos, Guatemala. Two of the 5 (40\%) specimens of caecilians contained an Eimeria species that is described here as new. This represents the first coccidia described from a gymnophionian host. Sporulated oocysts are spheroidal to subspheroidal, $19.5 \times 17.7(16-23 \times 15-21) \mu \mathrm{m}$, micropyle and oocyst residuum are absent, and 3 (or more) polar granules are always present. Sporocysts are ovoidal, $11.0 \times 7.2(10-12 \times 6-9)$; a Stieda body and sporocyst residuum are present.
\end{abstract}

Caecilians represent 1 of the 3 major groups of extant amphibians, the other 2 being frogs and salamanders. They are limbless and have vestigial eyes, elongate bodies, and many specialized morphological structures. Inhabitants of the lowland tropics and requiring moisture like all amphibians, caecilians have either fossorial or aquatic lifestyles. The caecilian Dermophis mexicanus (Duméril and Bibron, 1841) Peters, 1880 is terrestrial and found in loose moist soil or under leaf litter. Its distribution ranges from southern Veracruz and Oaxaca, Mexico, to Colombia (Campbell, 1998). The diet of burrowing caecilians is thought to consist mainly of earthworms and termites (Taylor, 1968). This is the first report of a coccidia from any species of the order Gymnophiona (family Caeciliidae), and it is described here as a new species.

\section{MATERIALS AND METHODS}

On 12 June 1998 about 3 dozen live plumbeous Central American caecilians were caught by hand on the grounds of Finca San Ignacio, shortly after the start of the seasonal rains. They were kept alive in plastic containers for approximately $24 \mathrm{hr}$. Five individuals were killed by injection with Nembutol and immediately dissected. Fresh feces were removed from the large intestine of each host and placed in separate snap-top glass vials containing $2.5 \%(\mathrm{w} / \mathrm{v})$ aqueous potassium dichromate $\left(\mathrm{K}_{2} \mathrm{Cr}_{2} \mathrm{O}_{7}\right)$. The samples were processed in the laboratory, measured, and photographed at the University of New Mexico, Albuquerque, New Mexico within 100 days of their collection in accordance with the guidelines of Duszynski and Wilber (1997). All measurements are in micrometers $(\mu \mathrm{m})$, with ranges in parentheses following the means.

\section{DESCRIPTION \\ Eimeria dermophis n. sp. \\ (Figs. 1-4)}

Sporulated oocysts $(\mathrm{n}=50)$ are spheroidal to subspheroidal, $19.5 \times$ $17.7(16-23 \times 15-21)$; shape index $(\mathrm{SI}=$ length/width $)=1.1(1.0-$ 1.4). Wall $\sim 1$, appears to be composed of 1 layer, pale yellow, with widely spaced bumps. Micropyle and oocyst residuum absent; 3 (or more) highly refractile polar granules present, each spherical, $\sim 1$ in diameter. Sporocysts $(\mathrm{n}=50)$ ovoidal, $11.0 \times 7.2(10-12 \times 6-9)$; SI $=1.5(1.2-2.0)$. Small, distinct Stieda body present; a small, indistinct substieda body may be present (Figs. 2, 3), but we were never able to resolve this completely to our satisfaction; parastieda body absent. Spo-

Received 28 May 1999; revised 30 August 1999; accepted 1 September 1999.

* Department of Biology, The University of Texas at Arlington, Arlington, Texas 76019. rocyst residuum composed of small to medium granules that completely fill the sporocyst. Sporozoites are mostly obscured by the sporocyst residuum but have a large, spherical, refractile body, $\sim 3-4$, at 1 end and a smaller refractile body at the opposite end.

\section{Taxonomic summary}

Type host: Dermophis mexicanus (Duméril and Bibron, 1841), plumbeous Central American caecilian (Caeciliidae: Caeciliinae).

Type locality: Central America: Guatemala, Departamento de San Marcos, Pacific versant on the lower slopes of Volcán Tajumulco, Finca San Ignacio, $14.941947^{\circ} \mathrm{N}, 92.033032^{\circ} \mathrm{W}$.

Prevalence: Two of $5(40 \%)$.

Site of infection: Unknown, oocysts collected from feces.

Material deposited: Photosyntypes of sporulated oocysts deposited in the U.S. National Parasite Collection (USNPC), Beltsville, Maryland, USNPC no. 88840 document no. 313; symbiotype host (Frey et al., 1992) deposited at the Herpetological Collection, the University of Texas at Arlington, UTA A-52165.

Etymology: The nomen triviale is derived from the generic name of the host.

\section{Remarks}

Although a few helminths have been recorded from caecilians (Ubelaker, 1966), this is the first coccidia species to be described from any member of the order Gymnophiona. One of the 2 hosts was very heavily infected; given the known diet of caecilians, we believe it is unlikely that these oocysts were from an infected food item.

Some molecular evidence indicates that Amphibia is monophyletic (Hedges and Maxson, 1993; Hay et al., 1995), although there has been continuous debate suggesting polyphylogeny (Rage, 1990). Caecilians make up 1 of the 3 orders of Lissamphibia, representing about 170 of the more than 4,000 species of the extant amphibians (Frost, 1985; Duellman, 1993). The relationship between Gymnophiona (caecilians), Caudata (salamanders), and Anura (frogs) has not been resolved. There are 2 current hypotheses for the systematic relationship between these orders. Molecular data suggest caecilians and salamanders as sister groups with frogs being derived separately (Hedges and Maxson, 1993; Hedges et al., 1993), whereas other data support salamanders and frogs as sister taxa with caecilians diverging earlier (Hay et al., 1995). Because of the difficulty determining the closest relative of the Gymnophiona and the relatively small number of Eimeria species described from all amphibians, it is both reasonable and possible to compare $E$. dermophis with other described eimerians from both anuran and caudatan hosts as recommended by the current International Code of Zoological Nomenclature (Ride et al., 1985).

At present, there are 18 named Eimeria species described from anuran hosts (Duszynski, Upton, and Couch, http://biology001.unm.edu/ $\sim$ coccidia/anura.html). Five of these have oocyst and sporocyst measurements that are similar to E. dermophis. Eimeria flexuosa Upton and McAllister, 1987, rarely has more than 1 polar granule and an unusual irregularly shaped oocyst with a wall that tightly adheres to the sporocysts. The oocyst wall appears to be smooth from the photomicrograph 

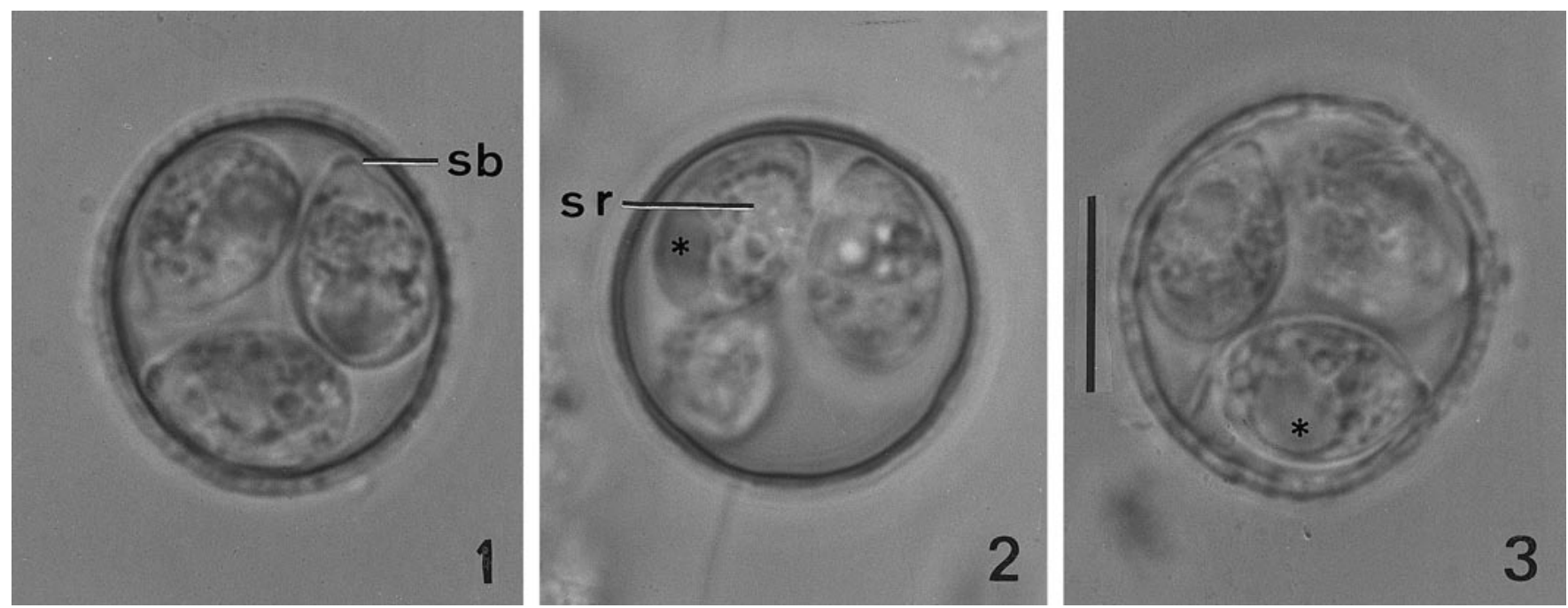

FIGURES 1-3. Photomicrographs of sporulated oocysts of Eimeria dermophis from Dermophis mexicanus collected in Guatemala, Central America. Scale bar $=10 \mu \mathrm{m}$. 1. Note the 2-layered oocyst wall with the rough outer wall showing a slightly striated appearance in optical crosssection; also, the button-like Stieda body on 2 of the sporocysts. 2. A spheroidal oocyst in which the sporocyst residuum, and a refractile body of 1 of the sporozoites is clearly seen; note the smooth, inner wall appears as a dark band. 3. A third oocyst focussed on its outer wall showing the distinctive striated appearance; both Stieda bodies on sporocysts and refractile bodies in sporozoites are seen. Abbreviations: sb, Stieda body at pointed end of sporocyst; sr, sporocyst residuum; *, refractile body of sporozoite.

(Upton and McAllister, 1987). Sporulated oocysts of Eimeria streckeri Upton and McAllister, 1987, Eimeria leptodactyli Carini, 1931, and Eimeria cyanophlyctis Chakravarty and Kar, 1944 all can be distinguished from E. dermophis by having a smooth wall, an oocyst residuum, and either rarely having a polar granule or lacking a polar granule (Pellérdy, 1974). Eimeria fitchi McAllister, Upton, Trauth, and Bursey, 1995 , differs from E. dermophis by having a smooth wall and lacking a polar granule.

Duszynski, Upton, and Couch (http://biology001.unm.edu/ coccidia/

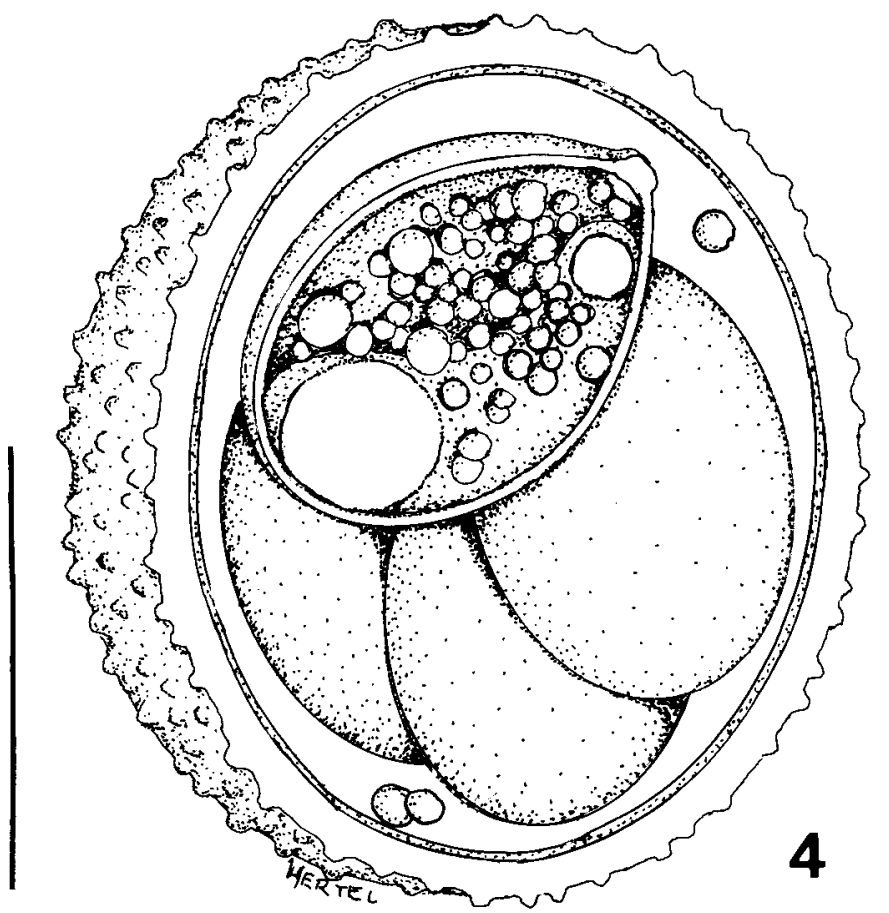

FiguRE 4. Line drawing of E. dermophis from D. mexicanus from Guatemala. Scale bar $=10 \mu \mathrm{m}$. caud.html) list 19 named Eimeria species described from caudata, most of which are much larger than E. dermophis. Based on oocyst and sporocyst size, there are only 3 species with sporulated oocysts that are similar to those of E. dermophis. Eimeria kingi Saxe, 1955, has a large globular oocyst residuum not seen in E. dermophis. Oocysts of Eimeria waltoni Saxe, 1955, are similar in size to those of E. dermophis, but the outer oocyst wall is smooth and it has an oocyst residuum that appears as a single refractile granule. Eimeria urodela Duszynski, Riddle, Anderson, and Mead, 1972, differs from E. dermophis by having a smooth oocyst wall, lacking polar granules, and possessing an oocyst residuum. For these reasons, we believe E. dermophis to be a valid new species.

\section{ACKNOWLEDGMENTS}

This work was supported by a Survey and Inventory grant (NSF, DEB 9705277) to J. A. Campbell, by a PEET grant (NSF, DEB 9521687) to D. W. Duszynski, and a Survey and Inventory grant (NSF, DEB 9505025) to D. W. Duszynski. Appreciation is extended to Lynn Hertel for the line drawing.

\section{LITERATURE CITED}

Campbell, J. A. 1998. Amphibians and reptiles of Northern Guatemala, the Yucatán, and Belize. University of Oklahoma Press, Norman, Oklahoma, $380 \mathrm{p}$.

DuEllman, W. E. 1993. Amphibian species of the world: Additions and corrections. University of Kansas Museum of Natural History Special Publication 21: 1-372.

DusZYNSKI, D. W., AND P. G. Wilber. 1997. A guideline for the preparation of species descriptions in the Eimeriidae. Journal of Parasitology 83: 333-336.

Frey, J. K., T. L. Yates, D. W. Duszynski, W. L. Gannon, and S. L. GARDNER. 1992. Designation and curatorial management of type host specimens (symbiotypes) for new parasite species. Journal of Parasitology 78: 930-932.

Frost, D. R. 1985. Amphibian species of the world, a taxonomic and geographical reference. Allen Press, Inc. and The Association of Systematics Collections, Lawrence, Kansas, 732 p.

Hay, J. M., I. Ruvinski, S. B. Hedges, and L. R. Maxson. 1995. Phylogenetic relationships of amphibian families inferred from DNA 
sequences of mitochondrial $12 \mathrm{~S}$ and $16 \mathrm{~S}$ ribosomal RNA genes. Molecular Biology and Evolution 12: 928-937.

Hedges, S. B., And L. R. MAXson. 1993. A molecular perspective on Lissamphibian phylogeny. Herpetological Monographs 7: 27-42. , R. A. Nussbaum, and L. R. Maxson. 1993. Caecilian phylogeny and biogeography inferred from mitochondrial DNA sequences of the 12s rRNA and 16s rRNA genes (Amphibia: Gymnophiona). Herpetological Monographs 7: 64-76.

Pellérdy, L. P. 1974. Coccidia and coccidiosis, 2nd ed. Verlag Paul Parey, Berlin, 959 p.

Rage, J. C. 1990. The classification of Amphibia: A difficult problem: Brief-history, current status and paleontological aspects. Bulletin de la Societe Zoologique de France_Evolution et Zoologie 115: 287-298.

Ride, W. D. L., C. W. Sabrosky, G. Bernardi, and R. V. Melville (eds.). 1985. International code of zoological nomenclature, 3rd ed. H. Charlesworth and Co. Ltd., Huddersfield, U.K., 338 p.

TAYLOR, E. H. 1968. The caecilians of the world. University of Kansas Press, Lawrence, Kansas, 848 p.

Ubelaker, J. E. 1966. Additional records of parasites from caecilians (Amphibia: Apoda). Journal of Parasitology 52: 431.

Upton, S. J., AND C. T. MCAllister. 1987. The coccidia (Apicomplexa: Eimeriidae) of Anura, with descriptions of four new species. Canadian Journal Zoology 66: 1822-1829. 


\section{ANNOUNCEMENT . .}

"Diagnostic Parisitology Course" is being offered July 31-August 11, 2000, at the Uniformed Services University of the Health Sciences, Bethesda, MD 20814-4799. This course will consist of a series of lectures and hands-on laboratory sessions covering the diagnosis of parasitic infections of humans. In addition to the examination of specimens, participants will be able to practice various methods used in the diagnosis of intestinal, blood, and tissue parasitic diseases. Parasitic diseases encountered throughout the world will be included. Slide presentations and videotapes will be available for study. The course will be held on the University's campus, utilizing up-to-date lecture rooms and laboratory facilities. Microscopes will be available on a loan basis and laboratory supplies will be provided. Certain reference specimens will also be available for personal use.

The registration fee for the two-week course is $\$ 1000$. Those interested should register as soon as possible, as the number of students will be limited. Previous laboratory experience is recommended.

For further information contact Dr. John H. Cross (301) 295-3139 or Ms. Ellen Goldman (301) 295-3129. FAX: (301) 295-1971. 